\title{
Diallyl disulfide-induced apoptosis in a breast-cancer cell line (MCF-7) may be caused by inhibition of histone de- acetylation
}

Article

Accepted Version

Altonsy, M., Habib, T. and Andrews, S. (2012) Diallyl disulfideinduced apoptosis in a breast-cancer cell line (MCF-7) may be caused by inhibition of histone de-acetylation. Nutrition and Cancer, 64 (8). pp. 1251-1260. ISSN 1532-7914 doi: https://doi.org/10.1080/01635581.2012.721156 Available at https://centaur.reading.ac.uk/39353/

It is advisable to refer to the publisher's version if you intend to cite from the work. See Guidance on citing.

Published version at: http://www.tandfonline.com/doi/abs/10.1080/01635581.2012.721156?url_ver=Z39.882003\&rfr_id=ori\%3Arid\%3Acrossref.org\&rfr_dat=cr_pub\%3Dpubmed\&\#.VOdBzS73TIQ

To link to this article DOI: http://dx.doi.org/10.1080/01635581.2012.721156

Publisher: Taylor \& Francis

All outputs in CentAUR are protected by Intellectual Property Rights law, including copyright law. Copyright and IPR is retained by the creators or other copyright holders. Terms and conditions for use of this material are defined in the End User Agreement. 


\section{CentAUR}

Central Archive at the University of Reading

Reading's research outputs online 


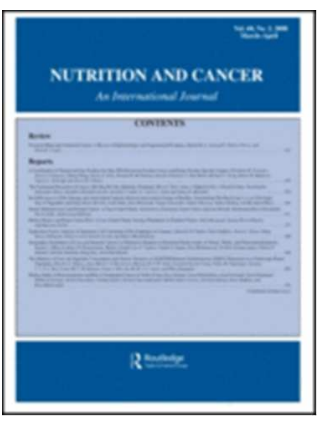

\section{Diallyl disulfide-induced apoptosis in a breast-cancer cell line (MCF-7) may be caused by inhibition of histone de- acetylation}

\begin{tabular}{|r|l|}
\hline Journal: & Nutrition and Cancer: An International Journal \\
\hline Manuscript ID: & N\&C-08-11-1132.R2 \\
\hline Manuscript Type: & Original Article \\
\hline Date Submitted by the Author: & n/a \\
\hline Keyworde List of Authors: & $\begin{array}{l}\text { Altonsy, Mohammed; Sohag University, Zoology Department } \\
\text { Habib, Tito; Sohag University, Zoology Department } \\
\text { Andrews, Simon; University of Reading, School of Biological Sciences; }\end{array}$ \\
\hline & $\begin{array}{l}\text { Apoptosis, Breast Cancer, Cancer Prevention, Caspases, Diet, Allium } \\
\text { (garlic) }\end{array}$ \\
\hline
\end{tabular}

\section{SCHOLARONE}

Manuscripts 
1 Diallyl disulfide-induced apoptosis in a breast-cancer cell line (MCF-7)

2 may be caused by inhibition of histone de-acetylation

3

Mohammed O. Altonsy ${ }^{\mathrm{a}}$, Tito N. Habib ${ }^{\mathrm{a}}$ and Simon C. Andrews ${ }^{*}$ b

$6{ }^{\mathrm{a}}$ Molecular Biology Lab., Zoology Department, Faculty of Science, Sohag University, $7 \quad 285224$, Egypt.

$8{ }^{\mathrm{b}}$ The School of Biological Sciences, University of Reading, Reading, RG6 6AJ, UK

9

10

11

For submission to: The International Journal of Nutrition and Cancer

12

13 


\begin{abstract}
19 Abstract
20 The health benefits of garlic have been proven by epidemiological and experimental studies.

21 Diallyl disulphide (DADS), the major organosulfur compound found in garlic oil, is known to

22 lower the incidence of breast cancer both in vitro and in vivo. The studies reported here

23 demonstrate that DADS induces apoptosis in the MCF-7 breast-cancer cell line through

24 interfering with cell-cycle growth phases in a way that increases the sub- $\mathrm{G}_{0}$ population and

25 substantially halts DNA synthesis. DADS also induces phosphatidylserine (PS) translocation

26 from the inner to the outer leaflet of the plasma membrane and activates caspase-3. Further

27 studies revealed that DADS modulates the cellular levels of Bax, Bcl-2, Bcl-xL and Bcl-w in

28 a dose-dependent manner, suggesting the involvement of Bcl-2 family proteins in DADS

29 induced apoptosis. Histone deacetylation inhibitors (HDACi) are known to suppress cancer

30 growth and induce apoptosis in cancer cells. Here it is shown that DADS has HDACi

31 properties in MCF-7 cells as it lowers the removal of an acetyl group from an acetylated

32 substrate and induces histone-4 (H4) hyper-acetylation. The data thus indicate that the

33 HDACi properties of DADS may be responsible for the induction of apoptosis in breast

34 cancer cells.
\end{abstract}

35 Keywords

36 Breast cancer, Diallyl disulphide, Apoptosis, Histone deacetylation inhibitor. 


\section{Introduction}

39 Worldwide, breast cancer comprises $22.9 \%$ of all non-melanoma skin cancers and $13.7 \%$ of

40 cancer deaths in women (1). Some of the primary risk factors for female breast cancer 41 include age (2), lack of childbearing or breastfeeding (3), high hormone levels (e.g. estrogen)

42 (4) and ethnicity (5). However, diet is another important factor that contributes to the 43 development of breast cancer (6-8). The impact of diet on the incidence of breast cancer is 44 indicated by geographic differences in the occurrence of the disease (9), and by the many 45 dietary components experimentally proven to act as anti-breast cancer agents. One such 46 dietary factors is diallyl disulphide (DADS), which is a major ( $\sim 60 \%)$ organosulfur 47 compound found in garlic oil (10). DADS inhibits the growth of breast cancer cell lines 48 (MDA-MB-231, KPL-1, MKL-F and MCF-7) (11) and reduces the incidence of $N$-methyl- $N$ 49 nitrosourea (MNU) and 2-amino-1-methyl-6-phenylimidazo-4-5-b-pyridine (PhIP)-induced 50 mammary tumours $(12,13)$. The anti-cancerous effect of DADS is often attributed to its 51 ability to induce apoptosis in cancer cells via cell-cycle arrest and modulation of the activity 52 of Bcl-2 family proteins (14-16).

53 The difference between normal and cancerous cells is that the later lack the ability to die. In 54 normal tissue, a balance between cell proliferation and cell death must be maintained, otherwise cells display uncontrolled growth and thereby cancer arises (17). Cellular apoptosis or programmed cell death is the key process in maintaining this balance. Apoptosis naturally occurs in mammalian tissues and is regulated by a cascade of cellular proteins, such as proand anti-apoptotic molecules. Prominent among such factors are the Bcl-2 family proteins

59 which act as signalling molecules in cellular apoptosis and survival pathways. Bcl-2 family 60 proteins include both pro-apoptotic (Bax, Bak, Bok, Bad, Bid, Bim and Bmf) and anti61 apoptotic members (Bcl-2, Bcl-xL, Bcl-w, Mcl-1 and Bfl-1/A1) (18, 19). Such pro-apoptotic 
62 proteins function by promoting mitochondrial permeability, resulting in the release of 63 apoptogenic factors (e.g. cytochrome $c$ and apoptosis inducing factor [AIF]) from the 64 mitochondrial inter-membrane space into the cytosol (20). The presence of such factors in the 65 cytosolic compartment induces the activation of protease activators (caspases) that ultimately 66 lead to apoptosis. Either increasing levels of pro-apoptotic Bcl-2 proteins or decreasing levels 67 of anti-apoptotic Bcl-2 proteins (or a combination of both) can result in activation of the 68 apoptotic machinery, thereby initiating apoptotic cell death. In this context, DADS up69 regulates pro-apoptotic Bcl-2 proteins in many types of cancerous cells. For example, DADS70 induces Bax expression and triggers the apoptotic mitochondrial pathway in MCF-7 human 71 breast cancer cells (14), and is known to induce apoptosis through down-regulation of anti72 apoptotic Bcl-2 in A549 human lung adenocarcinoma cells (21). DADS also caused down73 regulation of the anti-apoptotic proteins $\mathrm{Bcl}-2$ and $\mathrm{Bcl}-\mathrm{xL}$ in a human colon cancer cell line 74 (COLO 205), whereas it induced up-regulation of the pro-apoptotic Bak and Bax proteins 75 (22). Furthermore, DADS treatment of a human prostate cancer cell line (PC-3) resulted in 76 increased cellular levels of pro-apoptotic BAX and BAD, but decreased Bcl-2 levels (23). In 77 a similar study by Arunkumar et al. (2007), the apoptotic impact of DADS in PC-3 cells were 78 accompanied by histone (H3 and H4) hyper acetylation (24).

79 Aberrant gene transcription is common in malignant cells, resulting in activation of some 80 genes and silencing of others $(25,26)$. Such changes in transcriptional status are often 81 correlated with alterations in histone acetylation with hyper-acetylation mediating activation 82 whilst de-acetylation promotes gene silencing $(27,28)$. Histone acetylation controls 83 transcription by facilitating or restraining the recruitment of transcription factors on to 84 associated promoter $(29,30)$. Histone acetylation has received considerable interest of late 85 because of its link to the pathogenesis of cancer. The progression of carcinogenesis involves 86 the transcriptional activation of 'inappropriate' genes (e.g. oncogenes, RAS, WNT, MYC, 
87 ERK, TRK and Bcr-Abl) at the expense of tumour suppressor genes (e.g. TP53, CDKN1B, 88 HNPCC, MEN1, APC, CD95, ST5, ST7, ST14 and BRCA) and pro-apoptotic genes (e.g. 89 pro-apoptotic Bcl-2 proteins) (31-35). Since aberrant transcription of Bcl-2 family genes is 90 often observed in breast cancer cells $(36,37)$, this raises the possibility that the modulation of 91 expression of such genes by DADS is mediated by DADS-induced histone deacetylation 92 inhibition (HDACi).

93 This possibility raised above is addressed here through the investigation of the effect of

94 DADS on the acetylation status of histones in the breast-cancer cell line, MCF-7. The data 95 confirm that DADS strongly induces apoptosis in MCF-7 cells, which is apparently caspase 96 dependent. DADS also enhances histone hyper-acetylation in MCF-7 cells, through its 97 HDACi activity, and promotes pro-apoptotic Bax but depresses anti-apoptotic Bcl-2, Bcl-xL 98 and Bcl-w. Thus, the anti-cancerous activity of DADS could arise from its HDACi effect.

\section{Materials and Methods}

\section{Cell line and treatment}

101 The human mammary gland adenocarcinoma cell line (MCF-7) (38) was kindly provided by

102 Professor A El-Tayeb (Assiut University) and cells were used following 43-51 passages.

103 Cells were cultured in Dulbecco's modified Eagles's minimum essential medium 104 (CAMBREX) supplemented with $10 \%$ heat-inactivated $\left(60^{\circ} \mathrm{C}, 30 \mathrm{~min}\right)$ fetal bovine serum 105 (FBS, CAMBREX) and antibiotics (100 U/ml penicillin, $100 \mu \mathrm{g} / \mathrm{ml}$ streptomycin), in six-well 106 tissue culture plates in a concentration of $10^{5}$ cells $/ \mathrm{ml}$ at $37{ }^{\circ} \mathrm{C}$ in a $5 \% \mathrm{CO}_{2} / 95 \%$ humidified 107 atmosphere. Culturing media were supplemented with DADS (Sigma, purity $\leq$ 80\%) 108 dissolved in dimethylsulfoxide [(DMSO), Aldrich, purity $\leq 95.5 \%)]$ in final concentrations of 1091,10 or $100 \mu \mathrm{M}$ DADS. The DMSO final concentration did not exceed $0.1 \%$ in all treatments 
110 including control cultures. Trichostatin A (TSA), at $1 \mu \mathrm{M}$ final concentration, was used to

111 inhibit histone deacetylase activities in positive control samples (39)

\section{Cell cycle analysis}

113 MCF-7 cells, treated and control, were harvested by trypsinization. The cells were washed 114 with phosphate buffered saline (PBS). Cells were then fixed by pipetting $1 \mathrm{ml}$ of cell 115 suspension (approximately $10^{6}$ cells $/ \mathrm{ml}$ ) was on to $4 \mathrm{ml}$ of absolute ethanol at $-20{ }^{\circ} \mathrm{C}$ in a 116 Falcon tube while vortexing at top speed. Fixed cells were re-hydrated in $5 \mathrm{ml}$ PBS for 15 $117 \mathrm{~min}$ at room temperature (RT). Finally, $3 \mathrm{mM}$ propidium iodide (PI) in staining buffer (100 $118 \mathrm{mM}$ Tris; $\mathrm{pH}$ 7.4, $150 \mathrm{mM} \mathrm{NaCl}, 1 \mathrm{mM} \mathrm{CaCl} 2,0.5 \mathrm{mM} \mathrm{MgCl2}, 0.1 \%$ NP-40) was added and 119 mixed by gentle pipetting. Pancreatic RNAase $(50 \mu \mathrm{lof} 10 \mu \mathrm{g} / \mathrm{ml}$ stock; Sigma) was added 120 and the cells were incubated for $2 \mathrm{~h}$ at $4{ }^{\circ} \mathrm{C}$. Cell cycle analysis was performed using a 121 FACScan Flow Cytometer (Becton Dickson) according to the manufacturer's protocol.

\section{Annexin V/PI test}

123 MCF-7 cells were tested for apoptosis induction by DADS using Annexin V-FITC/PI double

124 staining. Briefly, approximately $10^{6}$ cells were washed in cold PBS followed by two washes 125 in binding buffer (10 mM HEPES, $140 \mathrm{mM} \mathrm{NaCl}, 2.5 \mathrm{mM} \mathrm{CaCl}_{2}, 5 \mathrm{mM} \mathrm{KCl}, 1 \mathrm{mM} \mathrm{MgCl}$, $126 \mathrm{pH}$ 7.4). Cells were then re-suspended in $100 \mu \mathrm{l}$ Annexin V-FITC (4 $\mu \mathrm{g} / \mathrm{ml}$ in binding buffer) 127 and incubated on ice for $10 \mathrm{~min}$. An additional $400 \mathrm{ml}$ of binding buffer, containing PI $128(2 \mu \mathrm{g} / \mathrm{ml})$, were added and the cellular suspension was incubated on ice for a further $15 \mathrm{~min}$. 129 Cells thus treated were then analysed by flow cytometry.

\section{Caspase-3 activation}

131 MCF-7 cells were seeded in 96-well plates at a density of $10^{5}$ cells/well. Plates were then 132 incubated overnight at $37^{\circ} \mathrm{C}$ in a ' $5 \% \mathrm{CO}_{2} / 95 \%$ humidity' atmosphere. DADS was added at 133 final concentrations of 1,10 and $100 \mu \mathrm{M}$ and cells were incubated for an additional 24 h. For 
134 positive controls, cells were treated with staurosporine $(3 \mu \mathrm{g} / \mathrm{ml})$ for $4 \mathrm{~h}(40)$ prior to 135 performing the assay. Caspase-3 activation upon DADS treatment was measured using the 136 Caspase-3 Fluorescence Assay Kit (Cayman chemicals) according to the manufacturer's 137 instructions. In order to test assay specificity, negative control samples were prepared by 138 adding $10 \mu \mathrm{l} /$ well of caspase-3 inhibitor solution (provided with the kit). The plates were read 139 on a FLUOstar OPTIMA fluorescent plate reader at $485 \mathrm{~nm}$ excitation and $535 \mathrm{~nm}$ emission 140 wavelengths.

\section{Cellular lysate preparation and Western blot}

142 Cells were lysed with Radio-Immuno Precipitation Assay (RIPA) lysis buffer (50 mM Tris$143 \mathrm{HCl}, \mathrm{pH} 8,150 \mathrm{mM} \mathrm{NaCl}, 0.02 \%$ sodium azide, $0.1 \%$ SDS, $100 \mu \mathrm{g} / \mathrm{ml}$ PMSF 144 [phenylmethylsulphonyl fluoride], $1 \mu \mathrm{g} / \mathrm{ml}$ aprotinin, 1\% NP-40) for $30 \mathrm{~min}$ on ice. The 145 cellular lysate was then centrifuged at $12,000 \times \mathrm{g}$ for $2 \mathrm{~min}$ at $4{ }^{\circ} \mathrm{C}$. The supernatant was then 146 transferred to a fresh Eppendorf tube, and total protein concentrations were determined using 147 the BioRad protein assay (41). Cellular lysates were then denatured with an equal volume of 148 loading buffer $(0.125 \mathrm{M}$ Tris- $\mathrm{HCl}, 4 \% \mathrm{SDS}, 20 \% \mathrm{v} / \mathrm{v}$ glycerol, $0.2 \mathrm{M}$ dithiothreitol, $0.02 \%$ 149 bromophenol blue, $\mathrm{pH} 6.8)$ at $100{ }^{\circ} \mathrm{C}$ for $10 \mathrm{~min}$. Protein samples $(50 \mu \mathrm{g})$ were then 150 immediately subjected to SDS-PAGE (BioRad Mini Protein II Electrophoresis gel) and trans151 blotted onto a nitrocellulose membrane (Amersham). The membranes were blocked in 5\% 152 non-fat dry milk in TBS $(20 \mathrm{mM}$ Tris- $\mathrm{HCl}, 500 \mathrm{mM} \mathrm{NaCl}, \mathrm{pH} 7.5)$ overnight at $4{ }^{\circ} \mathrm{C}$. The 153 membranes were immuno-stained for pro-apoptotic (Bax, Bak and Bid) and anti-apoptotic 154 Bcl-2 proteins (Bcl-2 and Bcl-xL [rabbit polyclonal, Abcam] and Bcl-w [Cell Signaling 155 Technology $\left.{ }^{\circledR}\right]$ ). $\beta$-Actin primary antibody (mouse monoclonal, Abcam) was used as a 156 loading control. Immuno-detected band visualisation was carried out using the 157 chemiluminescent alkaline phosphatase substrate (Immobilom ${ }^{\mathrm{TM}}$ Western). 
158 Histone extraction and electrophoresis

159 Histone extraction was performed as previously published (42). Approximately $10^{7}$ cells, 160 treated and control, were resuspended in $1 \mathrm{ml}$ nuclear extraction buffer $(60 \mathrm{mM} \mathrm{KCI}, 15 \mathrm{mM}$

$161 \mathrm{NaCl}, 3 \mathrm{mM} \mathrm{MgCl} 2,15 \mathrm{mM}$ piperazine- N/N' bis [2 ethanesulfonic acid]; $\mathrm{pH}$ 6.5, 0.1\% NP$16240,0.5 \mathrm{mM}$ phenyl methyl sulfonyl fluoride, $1 \mathrm{mM}$ tetrathionate) and kept on ice for $20 \mathrm{~min}$, 163 and then centrifuged at $1300 \mathrm{xg}$ and $4{ }^{\circ} \mathrm{C}$ for $10 \mathrm{~min}$. The resulting nuclear pellet was 164 suspended in $\mathrm{H}_{2} \mathrm{SO}_{4}\left(0.2 \mathrm{M}\right.$ final concentration) for $2 \mathrm{~h}$ and centrifuged at $10,000 \mathrm{xg}$ and $4{ }^{\circ} \mathrm{C}$ 165 for $10 \mathrm{~min}$. The supernatants containing the histones were removed, and dissolved histones 166 were precipitated with absolute alcohol at $-20{ }^{\circ} \mathrm{C}$. The precipitant was suspended in water and 167 quantified by Bio-Rad protein assay (41). A $1 \mathrm{ml}$ volume of sample buffer was prepared by 168 mixing $7.7 \mathrm{mg}$ dithiothreitol (DTT), $900 \mu \mathrm{l}$ of $8 \mathrm{M}$ urea, $50 \mu 1$ phenolphthalein $[1 \% \mathrm{w} / \mathrm{v}$ in $16995 \%$ ethanol] and $50 \mu \mathrm{l}$ of $30 \% \mathrm{NH}_{4} \mathrm{OH}$. The sample buffer was then added to the dissolved 170 histones in a 1:1 v/v ratio, and kept for $5 \mathrm{~min}$ at RT. Samples were then acidified by adding $1715 \mu 1$ of glacial acetic acid. Histones were electrophoresed in a Triton-Aced-Urea (TAU) gel as 172 described previously (43).

173 Nuclear extract preparation and DADS-HDACi activity analysis

174 Nuclear extracts were prepared as described before (44). Approximately $10^{7}$ cells were lysed 175 in $1 \mathrm{ml}$ of ice cold lysis buffer $(10 \mathrm{mM}$ Tris-HCl, $10 \mathrm{mM} \mathrm{NaCl}, 15 \mathrm{mM} \mathrm{MgCl}, 250 \mathrm{mM}$ 176 sucrose, $0.1 \mathrm{mM}$ ethylene glycol bis-[beta-aminoethylether] N,N,N[1]-tetraacetic acid 177 [EGTA], 0.5\% NP-40; $\mathrm{pH} 7.5$ ), and kept on ice for $15 \mathrm{~min}$. The suspension was then 178 carefully pipetted over a $4 \mathrm{ml}$ layer of sucrose buffer ( $30 \%$ sucrose, $10 \mathrm{mM}$ Tris- $\mathrm{HCl}, 10 \mathrm{mM}$ $179 \mathrm{NaCl}, 3 \mathrm{mM} \mathrm{MgCl} 2, \mathrm{pH} 7.5)$, and centrifuged at $1300 \mathrm{xg}$ and $4{ }^{\circ} \mathrm{C}$ for $10 \mathrm{~min}$. The pellet was 180 resuspended in Tris- $\mathrm{HCl}$ buffer $(10 \mathrm{mM}$ Tris- $\mathrm{HCl}, 10 \mathrm{mM} \mathrm{NaCl}, \mathrm{pH} 7.5)$ and centrifuged at $1811300 \mathrm{xg}, 4{ }^{\circ} \mathrm{C}$ for $10 \mathrm{~min}$. The pellet (nuclear fraction) was re-suspended in extraction buffer 182 (50 mM HEPES, $420 \mathrm{mM} \mathrm{NaCl}, 0.5$ mM EDTA, 0.1 mM EGTA, 10\% glycerol, pH 7.5) and 
183 ultrasonicated for $30 \mathrm{~s}$ and kept on ice for $30 \mathrm{~min}$. The mixture was then centrifuged at $18410,000 \mathrm{xg}$ and $4{ }^{\circ} \mathrm{C}$ for $10 \mathrm{~min}$. The supernatant (nuclear extract) was collected and kept at $18580^{\circ} \mathrm{C}$ for HDAC activity analysis. Different concentrations of DADS were tested for HDACi

186 activity, using the fluor de lys $^{\mathrm{TM}}$ fluorescent assay system (Drug discovery kit-AK-500;

187 BIOMOL) according to the manufacture instructions. The kit includes deacetylases inhibitor 188 (Trichostatin A [TSA]) for use as positive control. The samples were quantified on a 189 FLUOstar OPTIMA fluorescent plate reader at $360 \mathrm{~nm}$ excitation and $460 \mathrm{~nm}$ emission 190 wavelengths.

191 Statistical Analysis

192 All data were obtained from three independent experiments, and all results are expressed as 193 mean \pm SE. We employed the two-tailed (or paired) Student's $t$-test, using Microsoft Excel, to 194 determine significant differences. In all analysis, differences with probability values $\leq 0.05$ 195 were considered significant.

198 Results

199 DADS induce cell-cycle arrest and apoptosis in MCF-7 cells

200 Cell-cycle analysis of MCF-7 cells treated with 0-100 $\mu$ M DADS showed that such treatment 201 causes changes in the occupation of the various stages of the cell cycle (Fig. 1). DADS 202 stimulated a concentration-dependent increase in the sub- $\mathrm{G}_{0}$ population (representing 203 apoptotic bodies and/or cells with fragmented DNA) combined with a corresponding 204 decrease in the S-phase population. Thus, $100 \mu \mathrm{M}$ DADS induces a $56.9 \%(p \leq 0.05)$ 205 reduction in the proportion of cells engaging in DNA synthesis (the S-phase population) 206 coupled with more than a tenfold increase (from 3.16 to $31.1 \% ; p \leq 0.05$ ) in the number of 207 apoptotic, sub- $G_{0}$ cells (Fig. 1). In contrast, the $G_{0} / G_{1}$ and $G_{2} / M$ populations were little 
208 affected by DADS (Fig. 1). The DADS induction of apoptosis was confirmed by Annexin

209 V/PI double staining which detects both early and late apoptotic cells (AV and PI stained 210 cells, respectively). Annexin V binds to phosphatidylserine (PS) translocated from the inner

211 leaflet of the plasma membrane (considered a hallmark of early apoptosis (45)). DADS 212 increased the number of early apoptotic cells from $11.0 \%$ (in untreated cells) to 18.2 ( $p \leq$ $2130.05), 23.2(p \leq 0.05)$ and $34.8 \%(p \leq 0.05)$ in 1,10 and $100 \mu \mathrm{M}$ treated cells, respectively.

214 Late apoptotic cells numbers were also increased in a dose-dependent manner from $7.17 \%$ in 215 untreated cells to $11.2(p \leq 0.05), 16.3(p \leq 0.05)$ and $24.9 \%(p \leq 0.05)$ in 1,10 and $100 \mu \mathrm{M}$

216 DADS treated cells (Fig. 2). Thus, the double-staining analysis indicates that $100 \mu \mathrm{M}$ DADS

217 increased total apoptotic cell numbers by more than threefold from 18.2 to $59.7 \%(p \leq 0.05)$

218 (Fig. 2), a result which closely matches that obtained by single labeling (Fig. 1).

\section{DADS increases caspase-3 activity in MCF-7 cells}

220 In order to determine whether activation of caspase- 3 might be involved in the observed 221 DADS-induced apoptosis of MCF-7 cells, such cells were tested for caspase-3 activity 222 following DADS treatment, by fluorescence assay. The results show that caspase-3 activity 223 increased by $80.8 \% \pm 24.9$ and $270 \% \pm 13.6$ in cells treated with 10 and $100 \mu \mathrm{M}$ DADS, 224 respectively, compared to untreated cells (Fig. 3). Indeed, the caspase-3 induction achieved 225 by the highest dose of DADS (370\%) was close to that obtained by staurosporine (500\%) (the 226 positive control). However, low concentrations $(1 \mu \mathrm{M})$ of DADS had no significant impact 227 on caspase-3 activation. 'Caspase-3 inhibitor' eliminated the effects of DADS on caspase-3 228 activity indicating that the increases in activity observed in the absence of inhibitor were 229 indeed caspase-3 specific (Fig. 3). These results show that DADS elicits a dose-dependent 230 stimulation of caspase-3 activity in MCF-7 cells (Fig. 3) which suggests that caspase-3 231 activation is a component of the DADS-dependent induction of apoptosis in MCF-7 cells. 
232 DADS modulates the expression of Bcl-2 proteins in MCF-7 cells

233 In order to further confirm that DADS induces apoptosis in breast cancer cells and to 234 determine the likely regulatory pathway involved, Western blotting was used to examine the 235 effect of DADS on the levels of three pro-apoptotic proteins (Bax, Bak and Bid) in MCF-7 236 cells. The results show that cellular levels of Bax were raised by $23.0 \% \pm 8.15$ and $32.4 \% \pm$ 237 7.83, respectively, by treatment with 10 and $100 \mu \mathrm{M}$ DADS, although levels were not notably 238 affected by DADS at $1 \mu \mathrm{M}$ (Fig. 4). In contrast, DADS failed to significantly increase the 239 levels of either Bak or Bid in MCF-7 cells (Fig. 4). However, all three of the anti-apoptotic 240 Bcl-2 proteins examined here were reduced by DADS treatment: 10 and $100 \mu \mathrm{M}$ DADS 241 decreased Bcl-2 cellular levels by $42.2 \% \pm 9.13$ and $64.4 \% \pm 9.7$; Bcl-xL cellular levels were 242 decreased by $33.3 \% \pm 8.7$ and $57.7 \% \pm 7.7$; and Bcl-w cellular levels were decreased by $243 \quad 38.1 \% \pm 8.4$ and $68.6 \% \pm 7.4$, respectively (Fig. 4). Thus, DADS at $10-100 \mu \mathrm{M}$ raises the 244 MCF-7 cellular levels of at least one pro-apoptotic Bcl-2 family protein (Bax) and decreases 245 those of at least three anti-apoptotic Bcl-2 proteins (Bcl-2, Bcl-xL and Bcl-w). These effects 246 are again fully consistent with the DADS-induced apoptosis reported above, and roles for 247 Bcl-2 proteins in modulating DADS-stimulated apoptosis in MCF-7 cells.

DADS induces $\mathrm{H}_{4}$ acetylation and inhibits the deacetylation activity of MCF-7 nuclear 250 extract

251 The above studies show that the apoptosis effect generated by DADS in MCF-7 cells 252 correlates with appropriate changes in the levels Bcl-2 family proteins. Previous work 253 suggests that such changes in protein levels may arise from alterations in expression caused 254 by modifications of histone acetylation status $(46,47)$. To determine whether the effects of 255 DADS might arise through alterations in histone acetylation, global changes in overall 
256 histone acetylation levels were assayed using TAU gel electrophoresis (Fig.5 I). This analysis

257 showed that histone 4 is primarily in the unacetylated and mono-acetylated forms in untreated 258 MCF-7 cells. However, following treatment with $1 \mu \mathrm{M}$ DADS, the di-acetylated form of 259 histone 4 became apparent as a minor species. As the DADS concentrations were raised more 260 so, the acetylation profiles were further altered as tri- and tetra-acetylated histone 4 became 261 increasingly apparent (Fig. 5I). Thus, DADS treatment raises the histone-4 acetylation status 262 of MCF-7 nuclear DNA.

263 To determine whether the increased histone acetylation levels are caused by DADS-mediated 264 inhibition of deacetylase activity, the effect of DADS on the ability of MCF-7 nuclear 265 extracts to remove acetyl groups from an acetylated substrate was investigated (Fig.5 II). The 266 addition of DADS, at 10 and $100 \mu \mathrm{M}$, to MCF-7 nuclear extracts diminished deacetylation 267 activities to $85.7 \% \pm 17.6$ and $64.2 \% \pm 12.9$ of that of controls, although $1 \mu \mathrm{M}$ DADS had no 268 significant effect. TSA, a potent deacetylases inhibitor (39), reduced deacetylation to $24.77 \%$

$269 \pm 7.6$ of that of the control, showing that the assay was effective in reporting deacetylation 270 inhibition. The results therefore suggest that the DADS-induced increase in acetylation of 271 histone 4 is caused by the ability of DADS to act as a direct HDAC inibitor.

\section{Discussion}

273 The health benefits and medicinal properties of garlic have long been known. Records dating 274 back to $1550 \mathrm{BC}$ describe garlic as a "wonder drug" for a variety of diseases (48). 275 Epidemiological studies report that high consumption of garlic decreases the risk of breast 276 cancer $(49,50)$. This effect has been attributed to DADS, which is present in garlic cloves at $277 \sim 140 \mathrm{mM}$ as the major organosulfur compound of garlic oil (51), since it inhibits the growth 278 of breast cancer cells in vitro through induction of apoptosis $(14,16)$. The effects of DADS 279 are not confined to cancerous cells; it has been shown that DADS suppresses hepatic P450 
280 2E1 protein expression and $N$-nitrosodimethylamine demethylase activity $(52,53)$. It is

281 suggested that this may affect the metabolic activation of procarcinogens and the clearance 282 rate of toxic metabolites (54).

283 It should be stressed that human studies on garlic consumption and cancer risk provide 284 limited evidence of any relationship between garlic intake and protection against cancer (55-

285 58). However, the value of such human studies is often limited by variability in the garlic 286 preparations taken and uncertainty concerning the amounts of garlic consumed (58), and it is 287 suggested that further human trials are required in order to establish whether dietary garlic 288 exhibits any anti-cancerous effects (59). Important factors affecting DADS availability in 289 food include alkalinity and processing, which highlights the need to consider various aspects 290 of diet, as well as the composition of the garlic, when assessing any health benefit of garlic in clinical trials (60-63). Although the direct exposure of human breast cancer cells to DADS (as performed here) fails to replicate the complexity of the whole human system, such studies 293 have the advantage of avoiding the problems raised above that are associated with diet 294 composition effects.

295 The studies reported here confirm that DADS is able to induce apoptosis in the breast cancer 296 cell line, MCF-7, by interfering with the cell cycle. DADS increased the sub-G $\mathrm{G}_{0}$, apoptotic 297 population in a dose-dependent manner and at the same time decreased the occupancy of the 298 S phase of the cycle, indicating an inhibition of DNA synthesis had occurred. These findings 299 are consistent with those reported previously $(11,16,64-67)$ where the growth inhibitory 300 properties of DADS were also attributed to its induction of apoptosis and reduction in DNA 301 synthesis in KPL-1, MCF-7, COLO 205, HCT-116 and B16F-10 cells. Examination of both 302 early (e.g. PS translocation) and late (e.g. caspase-3 activation) molecular events 303 characteristic of apoptosis confirmed the ability of DADS, at physiologically relevant 304 concentration $(10-100 \mu \mathrm{M})$, to induce apoptosis in MCF-7 cells. 
305 Bcl-2 family proteins play an important role in the progression of apoptosis through

306 controlling the release of apoptogenic factors, e.g. cytochrome $c$ and 'apoptosis-inducing

307 factor' (AIF), from the mitochondrial inter-membrane space into the cytosol $(20,68)$.

308 Released cytochrome $c$ binds to cytosolic Apaf-1 to form the 'apoptosome' in a reaction that

309 eventually leads to the autoactivation of pro-caspase-9 (69) which in turn activates the

310 effector caspases (-3, -6 and -7) leading to apoptosis (70). Released AIF is translocated to the

311 nucleus where it induces DNA fragmentation (71). The balance between the levels of pro-

312 and anti-apoptotic proteins within the cell is crucial in determining whether apoptosis

313 progresses (72). The involvement of Bcl-2 family proteins in DADS-induced apoptosis in

314 MCF-7 cells was suggested (Fig. 4) by the DADS-dependent increase of the cellular levels of

315 pro-apoptotic Bax and concomitant decreases of anti-apoptotic Bcl-2, Bcl-xL and Bcl-w. The

316 results therefore suggest the involvement of Bcl-2 family proteins in the progression of

317 DADS-induced caspase-dependent apoptosis in MCF-7 cells. The results reported here are in

318 accordance with previous work (14), where DADS was shown to cause caspase-dependent

319 apoptosis in human breast cancer cells MCF-7 through the Bax-triggered mitochondrial

320 pathway. The involvement of Bcl-2 family proteins in DADS-induced apoptosis was also

321 shown in human lung adenocarcinoma A549 cells (21), where a decrease in the expression of

322 Bcl-2 (but no change of Bax levels) was elicited by treatment with $200 \mu \mathrm{M}$ DADS for $24 \mathrm{~h}$.

323 Interest in HDAC inhibitors has risen recently because of their anticancer potential; various

324 HDACi have the ability to suppress cancer growth and induce apoptosis in vitro in cancer cell

325 cultures and in vivo in tumor bearing animal models (73-76). In this study, it was shown that

326 DADS has HDACi properties when presented at relatively low concentrations $(10-100 \mu \mathrm{M})$

327 that are likely to be well within dietary concentrations ranges (51). Low concentrations of

328 DADS were found to inhibit the removal of the acetyl group from an acetylated substrate

329 through reducing the HDAC enzymatic activity of MCF-7 nuclear extracts by up to $35.8 \%$. 
330 Furthermore, the appearance of di-, tri- and tetra-acetylated H4 in DADS-treated cells

331 demonstrated the induction of histone hyper-acetylation by DADS. Induction of cellular 332 changes characteristic of apoptosis, such as cell cycle arrest, cellular senescence, and 333 activation of cell death in cancerous cells upon the treatment with a variety of HDAC 334 inhibitors, has been confirmed in many studies, although the underlying mechanisms are not 335 entirely clear (77-79). Such apoptotic changes were clearly seen here in DADS-exposed 336 MCF-7 cells. Previous studies have shown that modulation of gene expression occurs upon 337 alteration of the acetylation status of associated histones. It is thought that histone hyper338 acetylation promotes localised chromatin de-condensation (80) which thereby facilitates 339 binding of transcriptional factors at cognate promoters, leading to induction of gene 340 expression. DADS is likely to operate similarly by inducing histone hyper-acetylation 341 through its HDACi activity resulting in alterations in the expression of various apoptosis 342 factors, such as the pro- and anti-apoptotic Bcl-2 family proteins as observed here. However, 343 the precise mechanism by which Bcl-2 family protein expression is modulated and apoptosis 344 is induced by DADS remains unclear. Similar effects were obtained when a renal tubular cell 345 line (RPTC) was treated with a histone deacetylase inhibitor (suberoylanilide hydroxamic 346 acid). This caused a decrease in Bcl-xL levels, while the expression levels of Bax and Bak 347 remained relatively constant (81). It is unlikely that all of the expression changes observed 348 here are a direct effect of histone acetylation status, since levels of Bcl-2, Bcl-xL and Bcl-w 349 were decreased (rather than increased) by DADS. Thus, further work is required to decipher 350 the precise manner in which DADS promotes apoptosis in MCF-7 breast cancer cells.

\section{Acknowledgments}


352 This work was supported by Zoology Department, Faculty of Science Sohag University,

353 Egypt. We would like to thank Professor M. F. El-Sayed for helping providing chemicals and

354 kits necessary to accomplish this study.

355

356 Abbreviations

357 DADS Diallyl disulphide

358 DMSO Dimethylsulfoxide

359 FBS Fetal bovine serum

360 HDAC Histone deacetylation

361 HDACi Histone deacetylation inhibitor

362 PBS Phosphate buffered saline

363 PI Propidium iodide

364 PS phosphatidylserine

365 RIPA Radio-Immuno Precipitation Assay

366 RT Room temperature

367 TSA Trichostatin A 


\section{References}

370 1. WHO. World most frequent cancers. 2008 [cited; Available from:

371

372

373

374

375

376

377

378

379

380

http://globocan.iarc. fr/factsheets/populations/factsheet.asp?uno=900.

2. Schonberg M A ,Marcantonio E R ,Ngo L, Li D ,Silliman R A, et al.s. Causes of Death and Relative Survival of Older Women After a Breast Cancer Diagnosis. J Clin Oncol. 2011;

3. Daniilidis A ,Giannoulis C ,Sardeli C ,Dinas K, Nasioutziki M, et al.s. Pregnancyassociated breast cancer--a review analysis. Eur J Gynaecol Oncol. 2011; 31: 485-90.

4. Yager J D and Davidson N Es. Estrogen carcinogenesis in breast cancer. N Engl J Med. 2006; 354: 270-82.

5. Reeder-Hayes K E ,Bainbridge J ,Meyer A M ,Amos K D ,Weiner B J, et al.s. Race and age disparities in receipt of sentinel lymph node biopsy for early-stage breast cancer. Breast Cancer Res Treat. 2011;

6. Spector D, Deroo L A and Sandler D Ps. Lifestyle Behaviors in Black and White Women With a Family History of Breast Cancer. Prev Med. 2011;

7. Moral R, Escrich R,Solanas M,Vela E,Costa I, et al.s. Diets High in Corn Oil or Extra-Virgin Olive Oil Provided From Weaning Advance Sexual Maturation and Differentially Modify Susceptibility to Mammary Carcinogenesis in Female Rats. Nutr Cancer. 2011; 1.

8. Stoddard F R, 2nd, Brooks A D, Eskin B A and Johannes G Js. Iodine alters gene expression in the MCF7 breast cancer cell line: evidence for an anti-estrogen effect of iodine. Int J Med Sci. 2008; 5: 189-96.

9. Hill M Js. Nutrition and human cancer. Ann N Y Acad Sci. 1997; 833: 68-78.

10. Dausch J G and Nixon D Ws. Garlic: a review of its relationship to malignant disease. Prev Med. 1990; 19: 346-61.

11. Nakagawa H, Tsuta K ,Kiuchi K ,Senzaki H , Tanaka K, et al.s. Growth inhibitory effects of diallyl disulfide on human breast cancer cell lines. Carcinogenesis. 2001; 22: 891-7.

12. Schaffer E M, Liu J Z, Green J, Dangler C A and Milner J As. Garlic and associated allyl sulfur components inhibit N-methyl-N-nitrosourea induced rat mammary carcinogenesis. Cancer Lett. 1996; 102: 199-204.

13. Suzui N, Sugie S, Rahman K M ,Ohnishi M,Yoshimi N, et al.s. Inhibitory effects of diallyl disulfide or aspirin on 2-amino-1-methyl-6-phenylimidazo[4,5-b]pyridineinduced mammary carcinogenesis in rats. Jpn J Cancer Res. 1997; 88: 705-11.

14. Nagaraj N S, Anilakumar K R and Singh O Vs. Diallyl disulfide causes caspasedependent apoptosis in human cancer cells through a Bax-triggered mitochondrial pathway. J Nutr Biochem. 2011; 21: 405-12.

15. Milner J As. Preclinical perspectives on garlic and cancer. J Nutr. 2006; 136: 827S$831 \mathrm{~S}$.

16. Jun Z,Suzuki M,Xiao J,Wen J,Talbot S G, et al.s. Comparative effects of natural and synthetic diallyl disulfide on apoptosis of human breast-cancer MCF-7 cells. Biotechnol Appl Biochem. 2009; 52: 113-9.

17. Melet A ,Song K ,Bucur O ,Jagani Z, Grassian A R, et al.s. Apoptotic pathways in tumor progression and therapy. Adv Exp Med Biol. 2008; 615: 47-79.

18. Zhou F, Yang Y and Xing Ds. Bcl-2 and Bcl-xL play important roles in the crosstalk between autophagy and apoptosis. Febs J. 2011; 278: 403-13.

19. Zong W X, Lindsten T, Ross A J, MacGregor G R and Thompson C Bs. BH3-only proteins that bind pro-survival Bcl-2 family members fail to induce apoptosis in the absence of Bax and Bak. Genes Dev. 2001; 15: 1481-6. 
418 20. Murphy E, Imahashi K and Steenbergen Cs. Bcl-2 regulation of mitochondrial energetics. Trends Cardiovasc Med. 2005; 15: 283-90.

420

421

422

423

424

425

426

427

428

429

430

431

432

433

434

435

436

437

438

439

440

441

442

443

444

445

446

447

448

449

450

451

452

453

454

455

456

457

458

459

460

461

462

463

464

465

21. $\mathrm{Wu} X \mathrm{X}, \mathrm{Hu} \mathrm{Y}$, Lamy E and Mersch-Sundermann Vs. Apoptosis induction in human lung adenocarcinoma cells by oil-soluble allyl sulfides: triggers, pathways, and modulators. Environ Mol Mutagen. 2009; 50: 266-75.

22. Yang J S ,Chen G W ,Hsia T C ,Ho H C ,Ho C C, et al.s. Diallyl disulfide induces apoptosis in human colon cancer cell line (COLO 205) through the induction of reactive oxygen species, endoplasmic reticulum stress, caspases casade and mitochondrial-dependent pathways. Food Chem Toxicol. 2009; 47: 171-9.

23. Gayathri R, Gunadharini D N ,Arunkumar A, Senthilkumar K, Krishnamoorthy G, et $a l . s$. Effects of diallyl disulfide (DADS) on expression of apoptosis associated proteins in androgen independent human prostate cancer cells (PC-3). Mol Cell Biochem. 2009; 320: 197-203.

24. Arunkumar A, Vijayababu M R, Gunadharini N, Krishnamoorthy G and Arunakaran Js. Induction of apoptosis and histone hyperacetylation by diallyl disulfide in prostate cancer cell line PC-3. Cancer Lett. 2007; 251: 59-67.

25. Jing G J ,Xu D H , Shi S L , Li Q F ,Wang S Y, et al.s. Aberrant expression and localization of hnRNP-A2/B1 is a common event in human gastric adenocarcinoma. $J$ Gastroenterol Hepatol. 2011; 26: 108-15.

26. Kanai M ,Hamada J ,Takada M ,Asano T ,Murakawa K, et al.s. Aberrant expressions of HOX genes in colorectal and hepatocellular carcinomas. Oncol Rep. 2011; 23: 84351.

27. Hashimoto Y, Akiyama Y, Otsubo T, Shimada S and Yuasa Ys. Involvement of epigenetically silenced microRNA-181c in gastric carcinogenesis. Carcinogenesis. 2011; 31: 777-84.

28. Takai N, Kawamata N,Walsh C S ,Gery S ,Desmond J C, et al.s. Discovery of epigenetically masked tumor suppressor genes in endometrial cancer. Mol Cancer Res. 2005; 3: 261-9.

29. Harrison M R, Georgiou A S, Spaink H P and Cunliffe V Ts. The epigenetic regulator Histone Deacetylase 1 promotes transcription of a core neurogenic programme in zebrafish embryos. BMC Genomics. 2011; 12: 24.

30. Haddad F, Jiang W, Bodell P W, Qin A X and Baldwin K Ms. Cardiac myosin heavy chain gene regulation by thyroid hormone involves altered histone modifications. $\mathrm{Am}$ J Physiol Heart Circ Physiol. 2011; 299: H1968-80.

31. Mellert H S ,Stanek T J ,Sykes S M ,Rauscher F J, 3rd ,Schultz D C, et al.s. Deacetylation of the DNA-binding domain regulates p53-mediated apoptosis. $J$ Biol Chem. 2011; 286: 4264-70.

32. Liu S ,Klisovic R B ,Vukosavljevic T ,Yu J ,Paschka P, et al.s. Targeting AML1/ETO-histone deacetylase repressor complex: a novel mechanism for valproic acid-mediated gene expression and cellular differentiation in AML1/ETO-positive acute myeloid leukemia cells. J Pharmacol Exp Ther. 2007; 321: 953-60.

33. Ohshiro K, Rayala S K, Wigerup C ,Pakala S B ,Natha R S, et al.s. Acetylationdependent oncogenic activity of metastasis-associated protein 1 co-regulator. EMBO Rep. 2011; 11: 691-7.

34. Cheong J W, Chong S Y ,Kim J Y ,Eom J I ,Jeung H K, et al.s. Induction of apoptosis by apicidin, a histone deacetylase inhibitor, via the activation of mitochondriadependent caspase cascades in human Bcr-Abl-positive leukemia cells. Clin Cancer Res. 2003; 9: 5018-27. 
35. Kai L, Samuel S K and Levenson A Ss. Resveratrol enhances p53 acetylation and apoptosis in prostate cancer by inhibiting MTA1/NuRD complex. Int J Cancer. 2011; 126: $1538-48$.

36. Wang X, Belguise K, Kersual N ,Kirsch K H ,Mineva N D, et al.s. Oestrogen signalling inhibits invasive phenotype by repressing RelB and its target BCL2. Nat Cell Biol. 2007; 9: 470-8.

37. Fahy B N, Schlieman M G, Mortenson M M, Virudachalam S and Bold R Js. Targeting BCL-2 overexpression in various human malignancies through NF-kappaB inhibition by the proteasome inhibitor bortezomib. Cancer Chemother Pharmacol. 2005; 56: 46-54.

38. McLeskey S W ,Zhang L ,Kharbanda S ,Kurebayashi J ,Lippman M E, et al.s. Fibroblast growth factor overexpressing breast carcinoma cells as models of angiogenesis and metastasis. Breast Cancer Res Treat. 1996; 39: 103-17.

39. Duong V ,Bret C ,Altucci L ,Mai A ,Duraffourd C, et al.s. Specific activity of class II histone deacetylases in human breast cancer cells. Mol Cancer Res. 2008; 6: 1908-19.

40. Xue L Y, Chiu S M and Oleinick N Ls. Staurosporine-induced death of MCF-7 human breast cancer cells: a distinction between caspase-3-dependent steps of apoptosis and the critical lethal lesions. Exp Cell Res. 2003; 283: 135-45.

41. Bradford M Ms. A rapid and sensitive method for the quantitation of microgram quantities of protein utilizing the principle of protein-dye binding. Anal Biochem. 1976; 72: 248-54.

42. Cousens L S and Alberts B Ms. Accessibility of newly synthesized chromatin to histone acetylase. J Biol Chem. 1982; 257: 3945-9.

43. Waterborg J Hs. Dynamics of histone acetylation in vivo. A function for acetylation turnover? Biochem Cell Biol. 2002; 80: 363-78.

44. Waldecker M ,Kautenburger T, Daumann H, Veeriah S ,Will F, et al.s. Histonedeacetylase inhibition and butyrate formation: Fecal slurry incubations with apple pectin and apple juice extracts. Nutrition. 2008; 24: 366-74.

45. van Heerde W L , Robert-Offerman S ,Dumont E, Hofstra L ,Doevendans P A, et al.s. Markers of apoptosis in cardiovascular tissues: focus on Annexin V. Cardiovasc Res. 2000; 45: 549-59.

46. Fortson W S ,Kayarthodi S ,Fujimura Y ,Xu H, Matthews R, et al.s. Histone deacetylase inhibitors, valproic acid and trichostatin-A induce apoptosis and affect acetylation status of p53 in ERG-positive prostate cancer cells. Int J Oncol. 2011; 39: 111-9.

47. Kim H, Kim S N ,Park Y S ,Kim N H ,Han J W, et al.s. HDAC inhibitors downregulate MRP2 expression in multidrug resistant cancer cells: implication for chemosensitization. Int J Oncol. 2010; 38: 807-12.

48. Block Es. The chemistry of garlic and onions. Sci Am. 1985; 252: 114-9.

49. Levi F, La Vecchia C, Gulie C and Negri Es. Dietary factors and breast cancer risk in Vaud, Switzerland. Nutr Cancer. 1993; 19: 327-35.

50. Challier B, Perarnau J M and Viel J Fs. Garlic, onion and cereal fibre as protective factors for breast cancer: a French case-control study. Eur J Epidemiol. 1998; 14: 737-47.

51. Athanasios C ,Kimbaris N G ,Siatis C S ,Pappas P A ,Tarantilis D J, et al.s. Quantitative analysis of garlic (Allium sativum) oil unsaturated acyclic components using FT-Raman spectroscopy Food Chemistry. 2006; 94: 287-295.

52. Wu C C ,Sheen L Y, Chen H W ,Kuo W W, Tsai S J, et al.s. Differential effects of garlic oil and its three major organosulfur components on the hepatic detoxification system in rats. J Agric Food Chem. 2002; 50: 378-83. 
516 53. Brady J F, Li D C, Ishizaki H and Yang C Ss. Effect of diallyl sulfide on rat liver microsomal nitrosamine metabolism and other monooxygenase activities. Cancer Res. 1988; 48: 5937-40.

54. Melino S, Sabelli R and Paci Ms. Allyl sulfur compounds and cellular detoxification system: effects and perspectives in cancer therapy. Amino Acids. 2011; 41: 103-12.

55. Dorant E, van den Brandt P A and Goldbohm R As. Allium vegetable consumption, garlic supplement intake, and female breast carcinoma incidence. Breast Cancer Res Treat. 1995; 33: 163-70.

56. Galeone $\mathrm{C}$,Pelucchi $\mathrm{C}$,Levi $\mathrm{F}$,Negri $\mathrm{E}$,Franceschi $\mathrm{S}$, et al.s. Onion and garlic use and human cancer. Am J Clin Nutr. 2006; 84: 1027-32.

57. Franceschi S ,Parpinel M ,La Vecchia C ,Favero A, Talamini R, et al.s. Role of different types of vegetables and fruit in the prevention of cancer of the colon, rectum, and breast. Epidemiology. 1998; 9: 338-41.

58. Kim J Y and Kwon Os. Garlic intake and cancer risk: an analysis using the Food and Drug Administration's evidence-based review system for the scientific evaluation of health claims. Am J Clin Nutr. 2009; 89: 257-64.

59. Rivlin R Ss. Can garlic reduce risk of cancer? Am J Clin Nutr. 2009; 89: 17-8.

60. Kice J L and Rogers T Es. Mechanisms of the alkaline hydrolysis of aryl thiolsulfinates and thiolsulfonates. J.Am.Chem.Soc. 1974; 96: 8009-8015.

61. Müller Bs. Analytische Bewertung von Knoblauchpräparaten Dtsch.Apoth.Ztg 1989; 129: 2500-2504.

62. Kerckhoffs D A, Brouns F, Hornstra G and Mensink R Ps. Effects on the human serum lipoprotein profile of beta-glucan, soy protein and isoflavones, plant sterols and stanols, garlic and tocotrienols. J Nutr. 2002; 132: 2494-2505.

63. Lawson L Ds. Garlic for total cholesterol reduction. Ann Intern Med. 2001; 35: 65-66.

64. Tsubura A, Lai Y C, Kuwata M, Uehara N and Yoshizawa Ks. Anticancer effects of garlic and garlic-derived compounds for breast cancer control. Anticancer Agents Med Chem. 2011; 11: 249-53.

65. Lai K C ,Hsu S C ,Kuo C L, Yang J S ,Ma C Y, et al.s. Diallyl sulfide, diallyl disulfide, and diallyl trisulfide inhibit migration and invasion in human colon cancer colo 205 cells through the inhibition of matrix metalloproteinase-2, -7, and -9 expressions. Environ Toxicol. 2011;

66. Pratheeshkumar P, Thejass P and Kutan Gs. Diallyl disulfide induces caspasedependent apoptosis via mitochondria-mediated intrinsic pathway in B16F-10 melanoma cells by up-regulating $\mathrm{p} 53$, caspase-3 and down-regulating proinflammatory cytokines and nuclear factor-kappabeta-mediated Bcl-2 activation. $J$ Environ Pathol Toxicol Oncol. 2010; 29: 113-25.

67. Song J D ,Lee S K, Kim K M ,Park S E ,Park S J, et al.s. Molecular mechanism of diallyl disulfide in cell cycle arrest and apoptosis in HCT-116 colon cancer cells. $J$ Biochem Mol Toxicol. 2009; 23: 71-9.

68. Reed J C, Jurgensmeier J M and Matsuyama Ss. Bcl-2 family proteins and mitochondria. Biochim Biophys Acta. 1998; 1366: 127-37.

69. Nakabayashi J and Sasaki As. A mathematical model for apoptosome assembly: the optimal cytochrome c/Apaf-1 ratio. J Theor Biol. 2006; 242: 280-7.

70. Onuki R, Kawasaki H, Baba T and Taira Ks. Analysis of a mitochondrial apoptotic pathway using Bid-targeted ribozymes in human MCF7 cells in the absence of a caspase-3-dependent pathway. Antisense Nucleic Acid Drug Dev. 2003; 13: 75-82.

71. Delavallee L, Cabon L, Galan-Malo P, Lorenzo H K and Susin S As. AIF-mediated caspase-independent necroptosis: a new chance for targeted therapeutics. IUBMB Life. 2010; 63: 221-32. 
72. Ploner C, Kofler R and Villunger As. Noxa: at the tip of the balance between life and death. Oncogene. 2008; 27 Suppl 1: S84-92.

568 73. Bhalla K Ns. Epigenetic and chromatin modifiers as targeted therapy of hematologic

\section{Vanhaecke T, Papeleu P, Elaut G and Rogiers Vs. Trichostatin A-like hydroxamate} histone deacetylase inhibitors as therapeutic agents: toxicological point of view. Curr Med Chem. 2004; 11: 1629-43.

75. Bolden J E, Peart M J and Johnstone R Ws. Anticancer activities of histone deacetylase inhibitors. Nat Rev Drug Discov. 2006; 5: 769-84.

76. Marks P A and Breslow Rs. Dimethyl sulfoxide to vorinostat: development of this histone deacetylase inhibitor as an anticancer drug. Nat Biotechnol. 2007; 25: 84-90.

77. Zhao X, Yang W, Shi C,Ma W ,Liu J, et al.s. The G1 phase arrest and apoptosis by intrinsic pathway induced by valproic acid inhibit proliferation of BGC-823 gastric carcinoma cells. Tumour Biol. 2011; 32: 335-46.

78. Chuang J Y and Hung J Js. Overexpression of HDAC1 induces cellular senescence by Sp1/PP2A/pRb pathway. Biochem Biophys Res Commun. 2011; 407: 587-92.

79. Thangaraju M ,Cresci G A ,Liu K, Ananth S ,Gnanaprakasam J P, et al.s. GPR109A is a G-protein-coupled receptor for the bacterial fermentation product butyrate and functions as a tumor suppressor in colon. Cancer Res. 2009; 69: 2826-32.

80. Kurdistani S K and Grunstein Ms. Histone acetylation and deacetylation in yeast. Nat Rev Mol Cell Biol. 2003; 4: 276-84.

81. Dong G, Wang L, Wang C Y, Yang T ,Kumar M V, et al.s. Induction of apoptosis in renal tubular cells by histone deacetylase inhibitors, a family of anticancer agents. $J$ Pharmacol Exp Ther. 2008; 325: 978-84. 


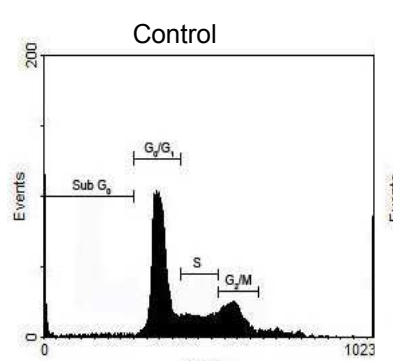

FLA-1

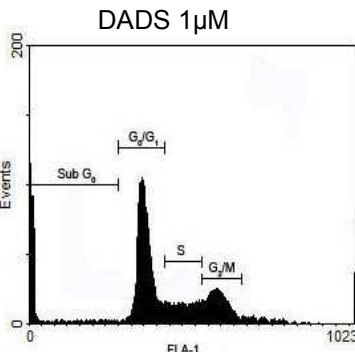

FLA-
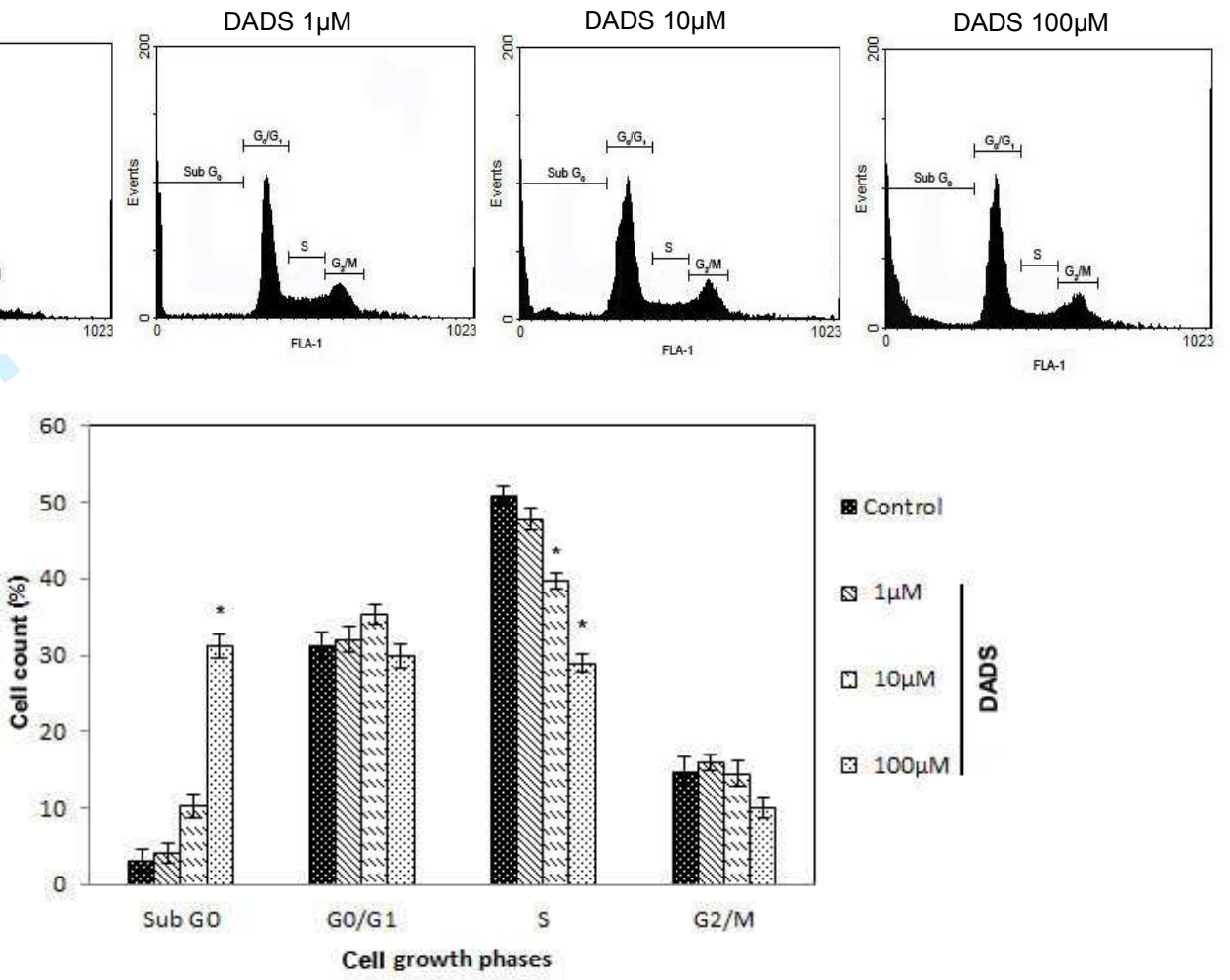

Figure 1: Cell-cycle analysis of PI labeled MCF-7 cells following treatment with 1, 10 and $100 \mu \mathrm{M}$ DADS for $24 \mathrm{~h}$. The results are reported as mean $\pm \mathrm{SE}$ of three independent experiments. *, significance $(p \leq 0.05)$. 

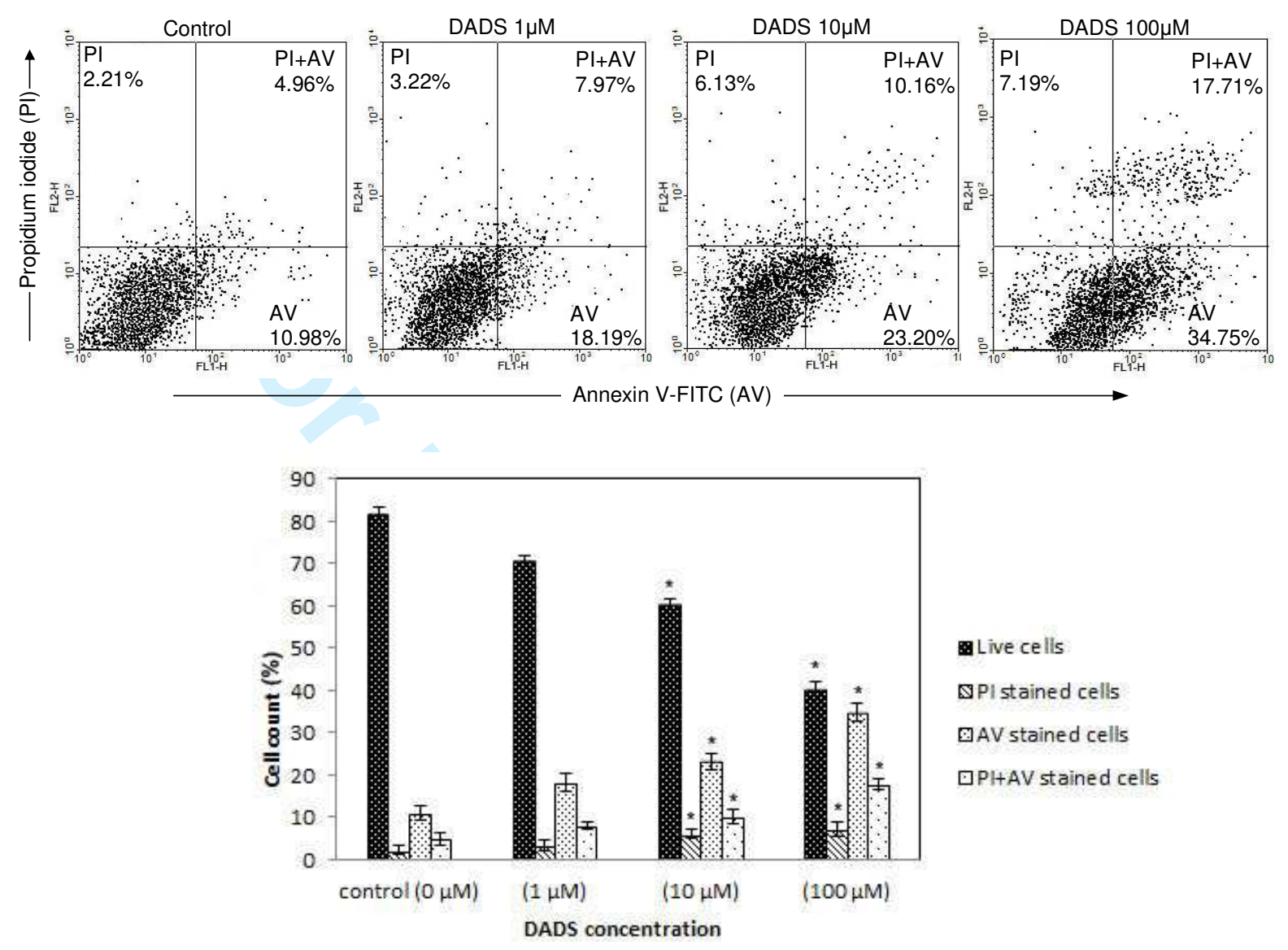

Figure 2: Estimation of the effect of DADS on the proportion of MCF-7 cells in late and early apoptotic states. The analysis was performed by flow-cytometry of Annexin V/PI-labeled cells following DADS $(1,10$ and $100 \mu \mathrm{M})$ treatment for $24 \mathrm{~h}$. The results are reported as mean $\pm \mathrm{SE}$ of three independent experiments. *, significant $(p \leq 0.05)$. 
Figure 3: Fluorescence assay of caspase-3 activity in MCF-7 cells following DADS (1, 10 and $100 \mu \mathrm{M}$ ) treatment for $24 \mathrm{~h}$. The positive control consists of MCF-7 cells treated as above except for the inclusion of the caspase- 3 inducer, staurosporine $(3 \mu \mathrm{g} / \mathrm{ml})$, for the final $4 \mathrm{~h}$. Negative controls were also obtained as above except that the inducer was replaced by a caspase- 3 inhibitor solution $(10 \mu \mathrm{l}$; see Methods) which was present for the entire $24 \mathrm{~h}$ growth period. The results are reported as mean $\pm \mathrm{SE}$ of three independent experiments. ${ }^{*}$, significant $(p \leq 0.05)$. 

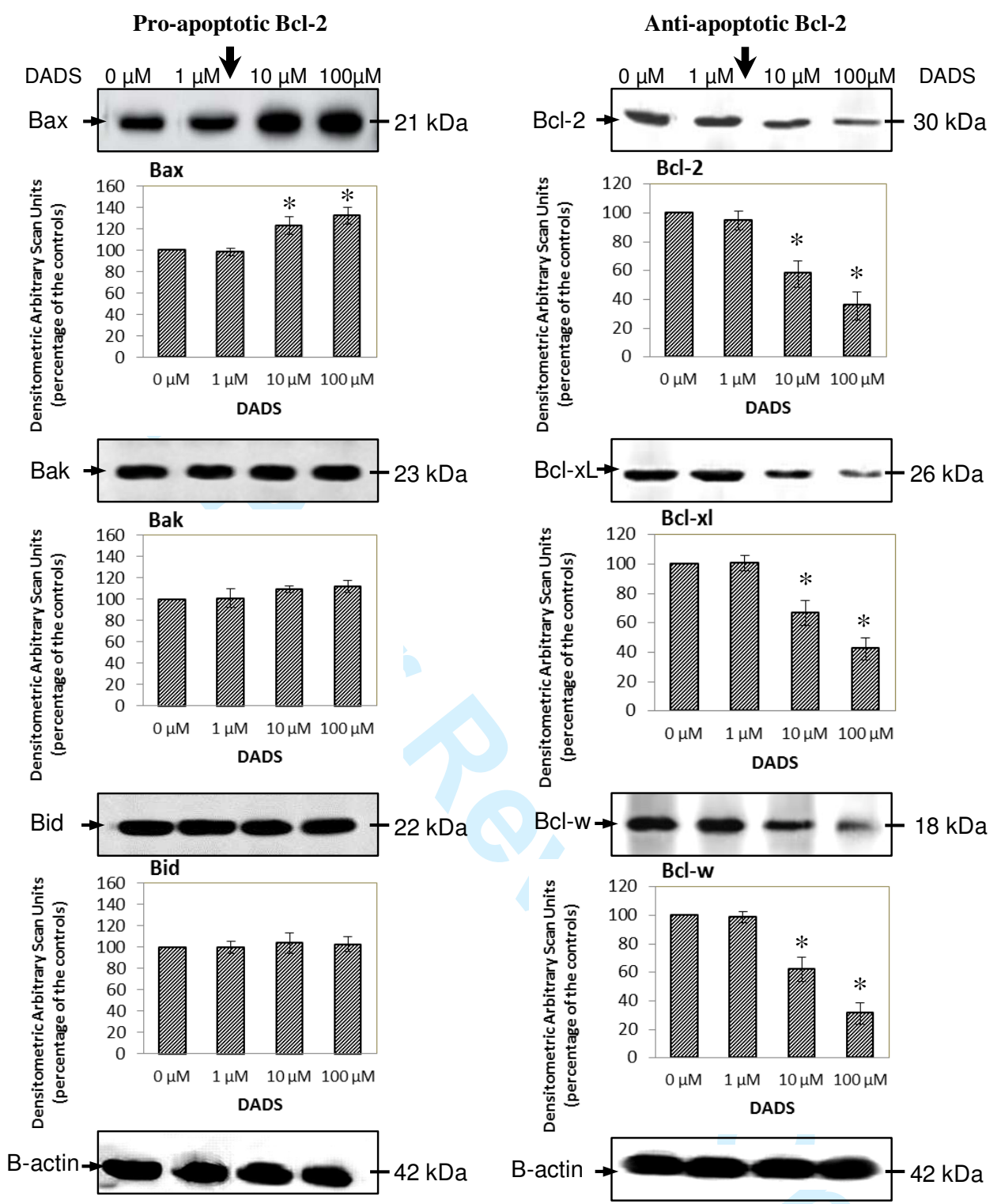

Figure 4: Western blot and densitometric analysis showing the effect of DADS on the levels of pro- and anti-apoptotic Bcl-2 proteins in MCF-7 cells. Cell cultures were treated with DADS for $24 \mathrm{~h}$. Loading control, $\beta$-actin detection. Densitometric analysis was performed using TotaLabTM software. The results are reported as mean $\pm \mathrm{SE}$ of three independent experiments. ${ }^{*}$, significant $(p \leq 0.05)$. 
(I)

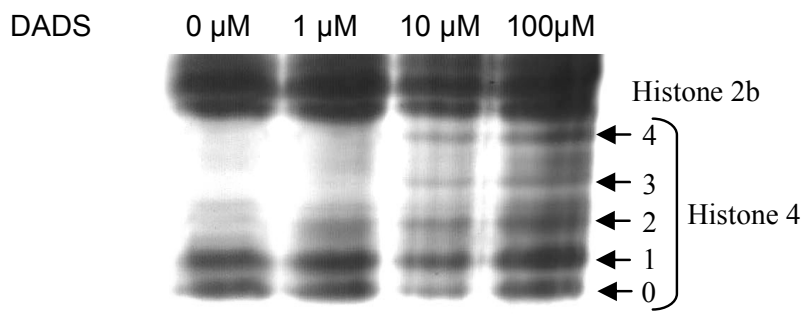

(II)

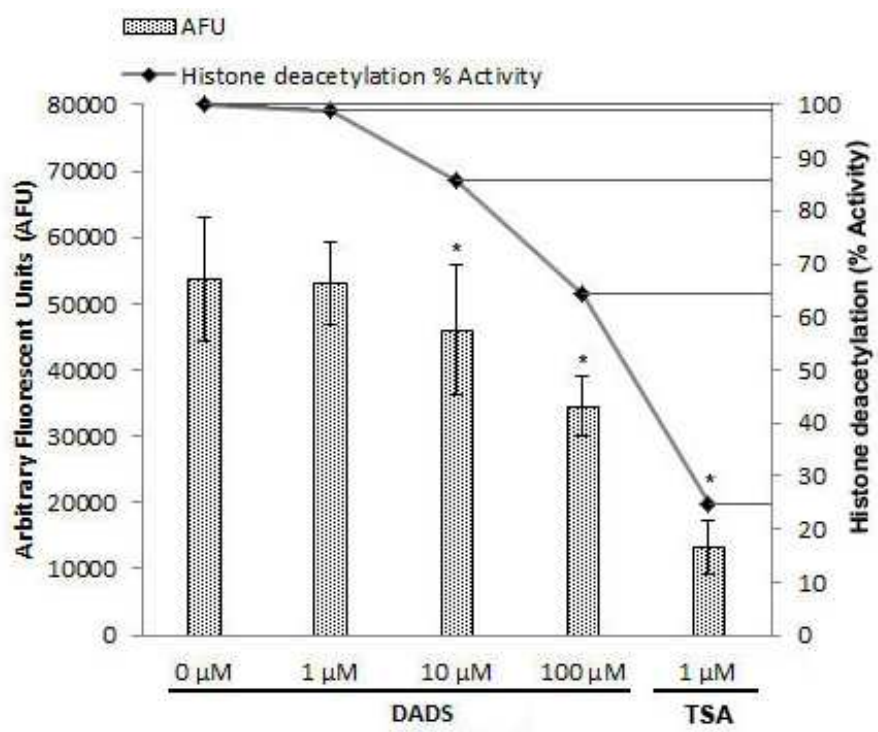

Figure 5: Effect of DADS on histone acetylation in Mcf-7 cells. (I) DADS induction (24 h) of histone 4 hyper-acetylation in MCF-7 cells, assessed by TAU gel electrophoresis as in materials and methods. (II) DADS inhibition of histone deacetylation in MCF-7 nuclear extracts as determined using the Fluor de Lys substrate (Fluorimetric Assay/Drug Discovery Kit; BIOMOL); data is represented as arbitrary fluorescent units and measured as a percentage of the fluorescence signal obtained with no addition of DADS or TSA to the reaction mixture. The results are reported as mean $\pm \mathrm{SE}$ of three independent experiments. *, significant $(p \leq 0.05)$. 